\title{
Nutritional and Therapeutic Benefits of Medicinal Plant Canthium parviflorum lam. (Rubiaceae): A Review
}

\author{
Srujana Paka ${ }^{1}$, Jyothsna Paleti ${ }^{1}$, Praneeth Reddy Naganagar ${ }^{1}$, Rikitha Ranga ${ }^{1}$, Bindu Priya Kalukuri ${ }^{1}$, Narender Boggula ${ }^{2 *}$
}

${ }^{1}$ School of Pharmacy, Anurag University, Venkatapur, Ghatkesar, Telangana, India

${ }^{2}$ Associate Professor, Department of Pharmaceutical Chemistry, School of Pharmacy, Anurag University, Venkatapur, Ghatkesar, Medchal, Hyderabad, Telangana, India

DOI: $10.36347 /$ sajp.2020.v09i07.004

| Received: 03.07.2020 | Accepted: 11.07.2020 | Published: 12.07.2020

*Corresponding author: Narender Boggula

\section{Abstract}

The medicinal plants are the key source in the life of human beings. The use of herbal drugs for the prevention and treatment of various health ailments has been in practice from time immemorial. A large number of medicinal plants are explored from flora for production of commercial drugs. Approximately $20 \%$ of the plants found in the world have been submitted to pharmacological or biological tests. Canthium parviflorum is an important medicinal plant used in indigenous system of medicine in India and abroad. Plants are the richest source of medicinal drugs. India is one of the richest Bio Source nations in the world. In India, infectious diseases are still a challenging health problem. To isolate and characterize biologically active molecules, many medicinal plants were screened. Though the medicinal importance of this plant is known, but the potential source of this plant for biologically active molecules is not known. So, the present review on Canthium parviflorum is opens a gateway to find out useful and novel drugs. The diversity of phytochemicals found present suggests that Canthium parviflorum thorn could serve as a source of useful drugs.

Keywords: Canthium parviflorum, phytochemicals, pulp, Balusu chettu, anti-cancer activity.

Copyright @ 2020: This is an open-access article distributed under the terms of the Creative Commons Attribution license which permits unrestricted use, distribution, and reproduction in any medium for non-commercial use (NonCommercial, or CC-BY-NC) provided the original author and source are credited.

\section{INTRODUCTION}

The traditional medicine all over the world is now a days revalue by an extensive activity of research on different plant species and their therapeutic principles. The increasing cost, non-availability of modern drugs, and limited access to adequate health care have compelled about $80 \%$ world population to use traditional pharmacopeia for primary health care especially in the tropical and sub-tropical regions [1].

Plants have been used by the human beings since time immemorial. Plants are significant sources of medicines that are used in the treatment of various categories of human diseases. Traditional drugs derived from herbal plants are used by about $60 \%$ of the world's population. India is a home to a variety of traditional medicine system that relies largely on native plant species for the raw drug material and holds a credibility of diverse social, cultural and medical heritage with an unbroken tradition coming down across millennia [2].

Herbal medicine has been practiced worldwide and it is recognized by World Health Organization (WHO) as essential building blocks for primary health care. WHO has estimated that up to $80 \%$ of people still rely on traditional remedies which are 21,000 plants around the world, among them 2500 species are in India, out of these 150 species are commercially used. Phytocompounds are synthesized by primary or rather secondary metabolism of living organism. Secondary metabolites are chemically and taxonomically extremely diverse compounds with obscure function. They are widely used in the human therapy, veterinary, agriculture, scientific research and countless other areas. The overall activity of herbal medicines depends on the active constituents present in them [3].

Traditional or indigenous medicine denotes medical practices developed by local ethnic people using natural herbs. Different world locations have their own history of traditional medicine. For example, Ayurveda medicine originated from Southeast Asia, Unani medicine originated from Arab countries in the Middle East, and acupuncture and Traditional Chinese Medicine (TCM) originated from China. Traditionally herbal medicines are used in folk medicine for the treatment of various health complications including inflammatory, cancerous, diabetic, hypertensive, and cardiovascular diseases. Medicinal plants are rich 
sources for new drug discovery as evidenced by some recent drugs that are from plant-derived compounds/derivatives. For example, success using classic traditional medicine includes salicylic acid and artemisinin, possibly the most effective medicinal natural products ever found. The use of traditional medicinal data in the drug discovery process results in new therapeutics, and identifies leads that undergo clinical trials. In general, it is believed that traditional medicines are safe and harmless as compared with modern drugs although this is seldom rigorously tested. Indications that the natural product extracts are effective against a particular pathological condition are based on the literature and do not imply that the effect has been proven using double blind studies with placebos. The modern approach has the goal to establish evidence-based use of traditional medicines, both locally and globally $[4,5]$.

The herb Canthium parviflorum belongs to the family Rubiaceae. It is a thorny shrub. The biological type for the genus consists of specimens originally described by Jean-Baptiste Lamarck as Canthium parviflorum [5].

Tribals like eating these leafy vegetables which are available everywhere naturally in the forest areas. This is a famous proverb in Andhra Pradesh 'One can eat Balusu koora if one is alive'. The tribals differently say this proverb as-'On should live to eat Balusu koora at least' (Telugu-Brathikunte Balusu aakulu thini brathukochu).

Table-1: Vernacular names

\begin{tabular}{|l|l|}
\hline Synonym & Plectronia parviflora (Lam.) Bedd. \\
\hline Ayurveda & Gandira \\
\hline Sanskrit & Gangeruki, Chayatinisha \\
\hline Telugu & Balusu chettu \\
\hline English & Carray cheddile, Wild Jasmine \\
\hline Hindi & Kirma, Kadbar \\
\hline Malayalam & Cherukara, Kandakara, Karamullu, Kara \\
\hline Tamil & Karai, Kadan Karai, Nalla Karai, Kudiram \\
\hline Kannada & Balasu, Ganduk-koral, Karee \\
\hline
\end{tabular}

\section{Habitat}

Canthium species are predominantly found in Southeast Asia, especially in Thailand and the Philippines. A small number of species is found in India, Sri Lanka, and Bangladesh. Only a limited number of species is found on the African continent, especially in Southern and East Africa. A rigid shrub or a small tree, occurring throughout the deccan peninsular from Gujarat to Maharashtra southwards and in Bihar and orrisa [6].

Table-2: Scientific classification

\begin{tabular}{|l|l|}
\hline Kingdom & Plantae \\
\hline Division & Magnoliophyta \\
\hline Class: & Magnoliopsida \\
\hline Order & Gentianales \\
\hline Family & Rubiaceae \\
\hline Subfamily & Ixoroideae \\
\hline Genus & Canthium \\
\hline Species & C. parviflorum \\
\hline Botanical Name & Canthium parviflorum Lam. \\
\hline
\end{tabular}

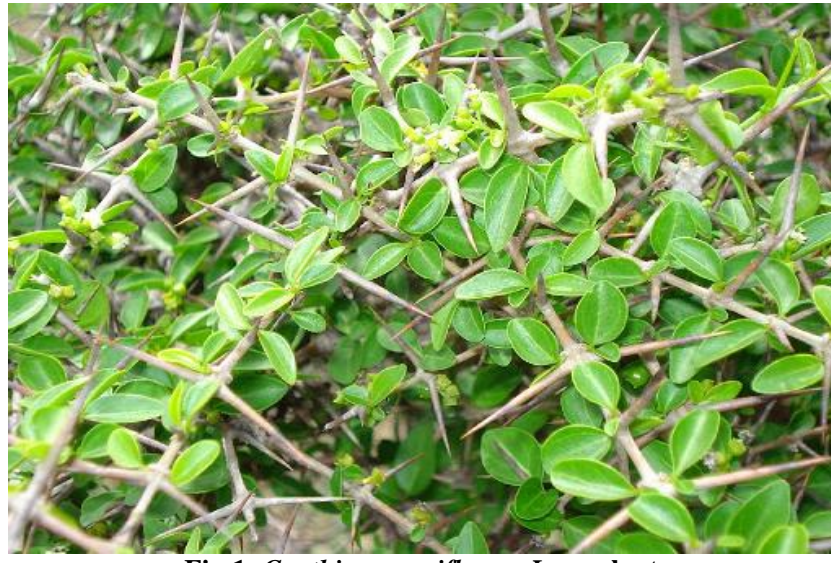

Fig-1: Canthium parviflorum Lam. plant 


\section{Morphology}

Canthium parviflorum is a thorny sub scandent shrub grows up to 3 meters height with spreading branches distributed throughout India in shrub forests and dry plains. Its leaves and roots are medicinally important and belong to the family Rubiaceae. Leaves are simple, opposite, small, and acute with axillary spines. Flowers are white, small in axillary cymes. Fruits are oblong two-chambered drupe, become yellow when ripe. All the plant parts such as roots, leaves, fruits and stems are pharmacologically useful $[6,7]$.

The leaves are simple and usually entire, and are opposite or sometimes whorled; stipules are present and interpetiolate. The flowers are nearly always bisexual and actinomormphic, often heterostylous, and usually are in cymose inflorescences. The calyx is somewhat reduced and 4-5 lobes or sometimes the lobes are absolute or rarely one of them greatly expanded and brightly colour. The sympetalous corolla is mostly 4-5 lobed, occasionally with 3 or up to 10 lobes. The androecium consists of as many stamens as corolla lobes and is adnate to the corolla tube or epigynous zone, alternate with the lobes. The gynoecium consists of a single compound pistil of 2 or seldom more carpels, a single style, and a nearly always inferior ovary with the number of locules [8-10].

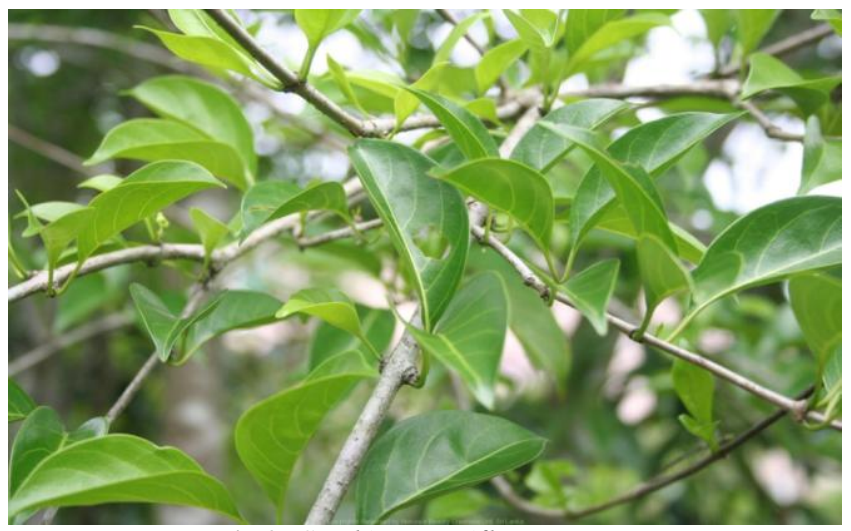

Fig-2: Canthium parviflorum leaves

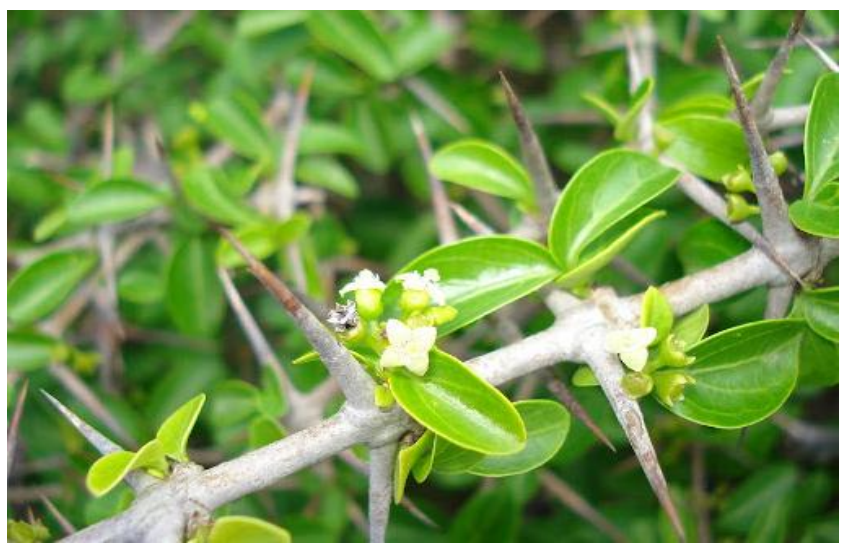

Fig-3: Canthium parviflorum flowers

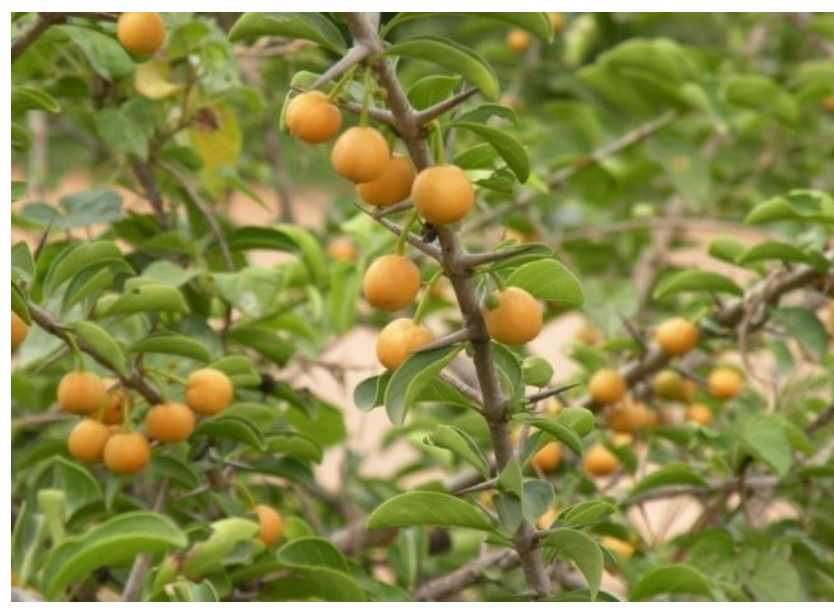

Fig-4: Canthium parviflorum fruits 


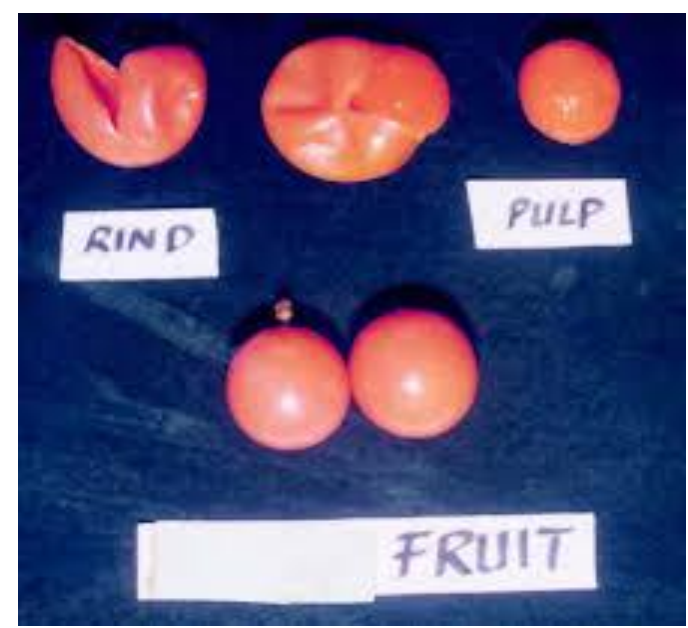

Fig-5: Canthium parviflorum fruit and pulp

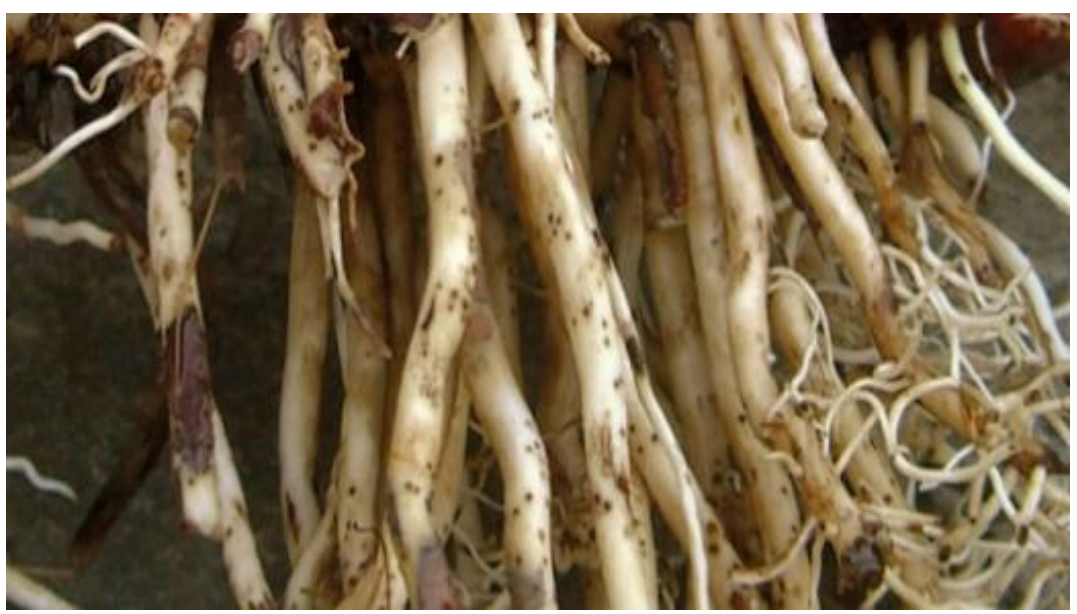

Fig-6: Canthium parviflorum roots

\section{Phytochemistry}

Plant drugs, therefore, continue to constitute an important part of the medicines used even today especially in the areas of modern medicine and also in traditional medical systems like in our traditional Ayurveda, Siddha and Unani as an immunomodulator. However, the potential use of higher plants as a source of new drugs is still poorly explored. Of the estimated 250,000-500,000 plant species, only a small percentage has been investigated phytochemically, and even a smaller percentage has not been properly studied in terms of their pharmacological properties. In most cases, only pharmacological screening or preliminary studies have been carried out and it is also estimated that only 8000 species have been studied for medicinal use [11].

Phytochemical analysis revealed the presence of secondary metabolites like alkaloids, flavonoids, tannins, steroids, saponins, terpenoids, sanranetin-4-Oglycoside long chain acids and cardiac glycosides in Canthium parviflorum leaf extracts. The Canthium parviflorum leaves with aqueous and methanol extracts revealed the presence of tannins, alkaloids, flavonoids, saponins, steroids, anthraquinones and reducing sugars. Canthium parviflorum leaves with hexane and ethanolic extracts revealed the presence of various biochemical compounds such as flavonoids, glycosides, alkaloids, saponins, tannins, phlobatannins, reducing sugars and terpenoids. The phytochemical screening revealed the presence of terpenoids, saponins, steroids, tannins, quinones and gums in Canthium parviflorum leaves [12-14].

Ethanolic extracts of Canthium parviflorum reported that the 22 active constituents present in the leaf which are later confirmed by GC-MS analysis; Biphenyl, 2-Methyl-4-heptanone, Di-isodectyl phthalate, 1,2,4,5-Tetroxane, 3,3,6.6-Tetraphenyl, 3oxo-alpha-ionol, Methyl-7-hydroxy-2-methyl-3,5octadienoate, 4-(2-Hydroxy-2,6,6-methyl cis-11,14,17icosatrienoate, trimethyl cyclohexyl)-3-buten-2-one, nhexadecanoic acid, E-11-Hexadecanoic acid, Ethyl ester, Ethyl hexadecanoate, Phytol, Ethyl (9Z,12Z)9,12-octadecanoate, Ethyl linolenate, 1-Hexadecanol, 2Phenoxyl-2-phenylpropanic acid, All-trans-squalene, Methyl linolenate, Gamma-Tocopherol, DEPH; 1,2Benzenedicarboxylicacid, bis (2-yl hexyl) ester, Stigmasterol and Gamma-stigmasterol. Based on the phytochemical results, it is concluded that Canthium parviflorum is most economically valuable plant $[15$, $16]$. 
Thorns and leaves of Canthium Parviflorum has taraxerol, d-mannitol, petunidin and B-sitosterol, sakuranetin-4'-O-glycoside valuable phytochemicals. Thorns of this plant have been found to contain taraxerol, d-mannitol, petunidin and long chain esters. The wild plant extracts of Canthium parviflorum contains phytochemicals such as alkaloids, oils, flavonoids, gums, phenols, saponins, steroids, tannins and terpenoids. The roots with ethyl acetate and crude methanol extracts of Canthium parviflorum showed glycosides, alkaloids, flavonoids, tannins and carbohydrates. Based on the qualitative phytochemical analysis it is concluded that the root material of Canthium parviflorum extracted with methanol, ethyl acetate, water, hexane and acetone contains betacyanin, acids, quinones, alkaloids, carbohydrates, terpenoids, fixed oils and fats, flavonoids, gums and mucilages, tannins, reducing sugars and volatile oils. Various phytochemicals like terpenoids, phenols, saponins, gums, oils and quinones are present in the seed extracts of Canthium parviflorum [17-19].

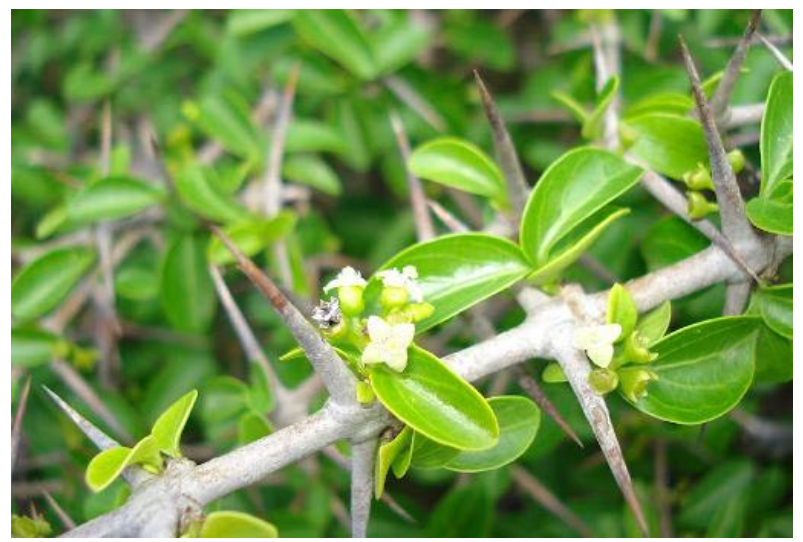

Fig-7: Canthium parviflorum thorns

Energy value and heavy metals $[20,21]$

The quantity of carbohydrate, protein and fat and heavy metals like nickel, lead and cadmium in the pulp are illustrated in Table 3 and 4.

Table-3: Energy value in the pulp of $C$. parviflorum

\begin{tabular}{|l|l|}
\hline Compounds & Quantity $\mathbf{( m g / g )}$ \\
\hline Carbohydrates & 42 \\
\hline Proteins & 27 \\
\hline Fat & 18 \\
\hline Energy & $43.8 \mathrm{kcal}$ \\
\hline
\end{tabular}

Table-4: Heavy metal composition in the pulp of $C$. parviflorum

\begin{tabular}{|l|l|}
\hline Metals & Quantity (mg/kg) \\
\hline Nickel & 4.2 \\
\hline Lead & 0.8 \\
\hline Cadmium & Nil \\
\hline
\end{tabular}

Table-5: Traditional importance

\begin{tabular}{|l|l|}
\hline Tissue & Use \\
\hline Leaf & $\begin{array}{l}\text { Since Canthium parviflorum leaf is used as an astringent, it was presumed that the leaf showed wound } \\
\text { healing property. Leaf paste is externally applied twice a day to treat scabies and the ringworm infection. } \\
\text { The Canthium parviflorum as herbal medicine is used for the treatment of diabetes among major tribal } \\
\text { groups in South Tamilnadu. Decoctions of leaves are used for wound healing in animals. }\end{array}$ \\
\hline Root & $\begin{array}{l}\text { The roots of this plant are traditionally used by the tribes of Orissa in the treatment of swelling of neck. The } \\
\text { roots are astringent, sweet, thermogenic, diuretic, febrifuge, constipating, anthelmintic, and tonic. They are } \\
\text { used in vitiated conditions of kapha, diarrhoea, strangury, fever, leucorrhoea, intestinal worms, and general } \\
\text { febility. }\end{array}$ \\
\hline $\begin{array}{l}\text { Fribes of Orissa state in India use fruits of this plant to treat a headache. It is traditionally used for snake } \\
\text { bites. The root material with methanol extract of } C \text {. parviflorum showed anthelmintic activity. The root and } \\
\text { leaf paste of } C \text {. parviflorum are very useful for diuretic. This plant contains high quantities of total } \\
\text { carotenoids and beta carotenoids which are very essential for vitamin A activity. }\end{array}$
\end{tabular}




\section{Traditional Uses}

Canthium parviflorum, belonging to the Rubiaceae was a valuable source of new secondary metabolites used in Ayurvedic system of medicine for various disorders. Traditionally, various parts of Canthium parviflorum were used to treat oedema, dysentery, spasm, scabies, diabetes etc. Rubiaceae species were a valuable source of new secondary metabolites for medical purposes. In Ayurvedic system of medicine, C. parviflorum used as laxative and also to cure gout. Canthium parviflorum plant is having germination problems and is frequently attacked by Meliola fungi. Based on the previous reports this plant material is used for its pharmacological importance as an anthelmintic, anti-dysenteric, anti-spasmodic and as a diuretic. Traditionally the roots and leaves are used to cure vitiated conditions of kapha in fever and constipation [22-25]. The leaves and fruits are edible. The $C$. parviflorum is the richest source of $\beta$-carotene and $100 \mathrm{~g}$ of edible fruit position contains $9.51 \mathrm{mg}$ carotenoids and $6.10 \mathrm{mg}$ of $\beta$-carotene [26].

\section{Ethnopharmacology}

A large number of medicinal plants still remain to be investigated for their possible pharmacological values. The ethnopharmacological values of Canthium parviflorum was given in the following Table-6.

Table-6: Ethnopharmacological values

\begin{tabular}{|l|l|l|}
\hline S. No & Pharmacological activity & Citation \\
\hline 1 & Anti-cancer activity & 27 \\
\hline 2 & Anti-diabetic activity & 28 \\
\hline 3 & Hypercholestermic activity & 29 \\
\hline 4 & Anti-microbial activity & 30,31 \\
\hline 5 & Anti-oxidant activity & 32,33 \\
\hline 6 & Anti-inflammatory activity & 14,34 \\
\hline 7 & Anti-pyretic and anti-diarrhoeal action & 34 \\
\hline 8 & Analgesic activity & 34 \\
\hline 9 & Anti-bacterial activity & 35 \\
\hline 10 & Wound healing and diuretic activities & 23 \\
\hline 11 & Anti-gout activity & 22,36 \\
\hline 12 & Anti-arthritic activity & 37 \\
\hline 13 & $\alpha$-Glucosidase inhibitory action & 38 \\
\hline 14 & Lipoxygenase inhibition activity & 38 \\
\hline 15 & Tyrosinase inhibition activity & 38 \\
\hline
\end{tabular}<smiles>CC(=O)O[C@H]1CC[C@]2(C)[C@@H]3CC[C@]4(C)C(=CC[C@]5(C)CCC(C)(C)C[C@]54C)[C@]3(C)CC[C@]2(C)C1(C)C</smiles>

A<smiles>COc1cc(-c2[o+]c3cc(O)cc(O)c3cc2O)cc(O)c1O</smiles>

B

Fig-8: Structures of (A) Taraxerol, (B) Petunidin<smiles>C/C(=C\CO)CCC[C@H](C)CCC[C@H](C)CCCC(C)C</smiles>

Fig-9: Structure of phytol

\section{Toxicity Studies}

A single administration of starting dose of $2000 \mathrm{mg} / \mathrm{kg}$ body weight $/$ p.o. of the ethanolic extract of C. parviflorum was administered to three female mice, and the mice were observed for three days to evaluate considerable changes in body weight and other signs of toxicity. Repeating the experiment with the same dose level of ethanolic extract of $C$. parviflorum for more seven days, we observed the body weight change and toxicity sign for totally fourteen days [39]. 


\section{CONCLUSION}

It is a well known that Traditional system of medicine always played an important role in meeting the global health care needs. Vast wealth of medicinal sources still has to use for curing a number of diseases. In order to find new sources of plant drugs, numbers of plants have been screened for various biological activities in various search institutions. Canthium parviflorum is an important medicinal plant used in indigenous system of medicine in India and abroad. So, based on these medicinal attributes concluded that Canthium parviflorum is most economically and pharmacologically valuable plant.

The use of herbal drugs for the prevention and treatment of various health ailments has been in practice from time immemorial. The present review summarizes information concerning the morphology, ethnopharmacology, phytochemistry, biological activities, clinical applications and toxicological reports of Canthium parviflorum. This review aims at gathering the research work undertaken till date on this plant in order to provide sufficient baseline information for future works and commercial exploitation. There needs to further investigate the studies on clinical trial, invitro and in-vivo studies.

The present overview has clearly revealed that, it will be beneficial to establish or to start pharmaceutical industry for the production of herbal drugs of purity, safety and high therapeutic values with more commercial profits. The present study also provides an opportunity to investigate and establish the status of Canthium parviflorum will find their use for the utilization in different ailments. It is anticipated that this work will provide some valuable information for ongoing explorations of this fascinating species and its phytochemicals. Future research on Canthium parviflorum would not only provide much needed knowledge on this popular herbal medicine, but would also offer a noticeable socio-economic impact in turning a common weed into beneficial nutraceutical and pharmaceutical products.

Author Contributions: All authors contributed to data collection, drafting or revising the article, gave final approval of the version to be published, and agree to be accountable for all aspects of the work.

Conflict of Interest: All authors declare that there is no conflict of interests regarding publication of this paper.

\section{Financial support and Sponsorship: None}

Ethical approval: Not required

\section{REFERENCES}

1. Sabannavar SJ and Chitra AS. Pharmacognostic analysis and phytochemical analysis of the medicinal plant Canthium parviflorum Lam. Int $\mathbf{J}$ Pharmacognosy. 2017; 4(3): 92-98.

2. Ncube NS, Afolayan AJ, Okoh AI. Assessment techniques of antimicrobial properties of natural compounds of plant origin: current methods and future trends. African Journal of Biotechnology. 2008; 7(12): 1797-1806.

3. Mangai PA. A drug review on Karai rasayanam a Siddha pediatric drug specified for acute nasopharyngitis in children. World journal of Pharmaceutical Research, 2018; 7(14): 503-516.

4. Rampilla V, Mahammad KS. Ethno-medicinal plants in sacred groves in east Godavari district, Andhrapradesh, India. European journal of medicinal plants, 2015; 9(4): 1-29.

5. Bridson DM. The genus Canthium (Rubiaceae Vanguerieae) in tropical Africa. Kew Bulletin. 1992; 47(3): 353-401.

6. Lantz H, Bremer B. Phylogeny of the complex Vanguerieae (Rubiaceae) genera Fadogia, Rytigynia, and Vangueria with close relatives and a new circumscription of Vangueria. Plant Systematics and Evolution. 2005; 253: 159-183.

7. Khare C. Canthium parviflorum Lam. In: Khare C. (eds) Indian Medicinal Plants. Springer, 2007, New York.

8. Pulate PV, Wagay Nasir Aziz, Deshmukh VR. Phytochemical, ethnomedicinal and anatomical study of Canthium parviflorum. World Journal of Pharmacy and Pharmaceutical Sciences. 2015; 4(11):1464-1482.

9. Rajyalakshmi P. Canthium parviflorum: an underexploited carotene rich fruit. Ind J Nat Prod Res. 2003; 2:70.

10. Priyadarshini S. Ekambe, and Babasaheb S. Surwase, "In vitro seed germination and plantlets development of Canthium coromandelicum (Burm. f.) Alston.," International Journal of Scientific and Technical Advancements. 2016; 2(1):21-23.

11. Johnson M, Wesely EG, Kavitha MS, Uma V. Antibacterial activity of leaves and inter-nodal callus extracts of Mentha arvensis L. Asian Pac J Trop Med. 2011; 4:196-200.

12. Sathish Kumar, T Shanmugam, S Palvannan, Bharathi Kumar VM. Evaluation of antioxidant properties of Canthium parviflorum Lam. Leaves. Indian J Nat Prod Resour. 2008; 7:122-6.

13. Sasidhar Pasumarthi, Murali Krishna Chimata, Chellu S Chetty, Suresh Challa. Screening of phytochemical compounds in selected medicinal plants of Deccan Plateau and their viability effects on Caco-2 cells. J Medicinal Plants Res. 2011; 5:6955-62.

14. Kandikattu Karthik, Bharath Rathna Kumar P, Venu Priya R, Sunil Kumar K, Ranjith Singh, B Rathore. Evaluation of anti-inflammatory activity of Canthium parviflorum by in vitro method. Indian J Res Pharm Biotechnol. 2013; 1:729-30. 
15. Ramanathan R, Bhuvaneswari R, Dhandapani R. Antimicrobial activity of Canthium parviflorum Lam. and Pergularia daemia (Forsk.). Int J Comprehensive Pharm. 2013; 9:34-8.

16. Purushoth Prabhu T, Panneerselvam P, Suresh R, Clement Atlee W, Balasubramanian S. GC-MS analysis of an ethanolic extract of Canthium parviflorum Lamk Leaf. J Appl Pharm Sci. 2013; 3:166-8.

17. Jose Beena, Jirovetz Leopold, Shafi PM. Phytochemical studies on the thorns and leaves of Canthium parviflorum Lam. Asian J Chem. 2008; 20:5372-6.

18. Haroled Peter PL, Abraham Shanjan, Godwin Blessing Issac A, Sanjay Das, Arasan Elayaraja. Preliminary phytochemical and antimicrobial screening of the whole plant extracts of Canthium parviflorum Lam. Int J Phytopharm Res. 2011; 2:30-4.

19. Shabi Ruskin R, Vasantha Kumari B, Chitarasu T. Qualitative phytochemical and ftir analysis of root extracts of Canthium parviflorum lam. J Chem Pharm Sci 2014; 2:122-7.

20. Prema G. Energy value and analysis of heavy metals in pulp of Canthium parviflorum. International Journal of Modern Pharmaceutical Research. 2019; 3(6):113-114.

21. Prabodhani M, Wansapala J. Nutritional and in vitro bioactive compounds analysis of Canthium coromandelicum leaves. International journal of food Science and Nutrition, 2018; 3(6): 268-271.

22. Jaikumar $\mathrm{S}$ et al. Protective effect of Canthium parviflorum against potassium oxonate induced hyperuricemia in rats. Int. J. of Res. in Pharmacology \& Pharmacotherapeutics. 2018; 7(3):228-232.

23. Mohideen S, Ilavarasan $\mathrm{R}$, Hemalatha AN, Sasikala E. Wound healing and diuretic activities of Canthium parviflorum Lam. KR Soc Pharmacog. 2006; 5:23-25.

24. Hosagoudar VB, Archana GR. Host range of meliolaceous fungi in India. $\mathbf{J}$ Threatened Taxa. 2009; 1:269-82.

25. Sirigiri Chandra Kala. A short review on callus studies of Canthium parviflorum Lam. Int J Institutional Pharm Life Sci. 2015; 5:76-80.

26. Salai Senthilkumar MS, D Vaidyanathan, D Sivakumar, M Ghouse Basha. The diversity of ethnomedicinal plants used by Malayali tribals in Yelagiri hills of Eastern ghats, Tamilnadu, India. Asian J Plant Sci Res. 2014; 4:69-80.

27. John D Milton, M Alvin Jose. In vitro and in vivo anticancer evaluation of Canthium parviflorum root extracts. Int J Adv Pharm Biol Sci. 2014;4:1724.

28. Gulati Vandana, Ian $\mathrm{H}$ Harding and Enzo A Palombo. Enzyme inhibitory and antioxidant activities of traditional medicinal plants: Potential application in the management of hyperglycemia. BMC Complementary and alternative medicine. 2012; 12:77.

29. Vanitha Reddy P, Lakshmi Sarkar and Asna Urooj. Inhibition of 3-hydroxy-3-methylglutaryl coenzyme A (HMG-CoA) reductase (ex vivo) by medicinal plants from Western Ghats. Annals of Phytomedicine. 2014, 3: 56-61.

30. Sathiya Priya P, Sasikumar, JM, Gowsigan, G. Antibacterial activity of methanol extract of Ruta chalapensis (L), Quercus infectoria (Oliver) and Canthium parviflorum (Lam). Ancient Sci. of Life, 2009, 29: 28-31.

31. Haroled Peter PL, Abraham Shanjan, Godwin Blessing Issac A, Sanjay Das, Arasan Elayaraja. Preliminary phytochemical and antimicrobial screening of the whole plant extracts of Canthium parviflorum Lam. Int J Phytopharm Res. 2011; 2:30-4.

32. Bhaskar Rajeswari V, Kumar TS. Evaluation of antioxidant properties of Canthium parviflorum Lam. Leaves. Indian J Nat Prod Resour. 2008; 7:122-6.

33. Purushoth Prabhu T, Selvakumar S, Clement Atlee W, Vijayakumar R, Suresh R. Antioxidant activity of ethanolic extract of Canthium Parviflorum lamk in alloxan induced diabetic rats. Int $\mathbf{J}$ Tradit Herb Med. 2012; 2:766:70.

34. P. Alarmel Mangai. A drug review on karai rasayanam a siddha pediatric drug specified for acute nasopharyngitis (neerkana mandham) in children. World Journal of Pharmaceutical Research. 2018; 7(14):503-516.

35. Sabannavar SJ and Chitra AS: Pharmacognostic analysis and phytochemical analysis of the medicinal plant Canthium parviflorum Lam. Int J Pharmacognosy. 2017; 4(3): 92-98.

36. Nguyen MT, Awale S, Tezuka Y, Tran QL, Watanabe H, Kadota S. Xanthine oxidase inhibitory activity of Vietnamese medicinal plants. Biol Pharm Bull. 2004; 27:1414-21.

37. Purushoth Prabhu T, Shine Sudev M, Deepak Venkataraman N, Clement Atlee W, Sapna S. In vitro antioxidant and antiarthritis activity of extracts and fractions of Canthium parviflorum. Eur J Biomed Pharm Sci. 2014, 1(3):533-41.

38. Sirigiri Chandra Kala, Kokkanti Mallikarjuna, Challa Siva Reddy. In vitro Pharmacological Investigations of Using Leaf Callus Extracts of Canthium parviflorum Lam. British Biotechnology Journal, 4(3): 325-338, 2014.

39. Purushoth Prabhu T, Panneerselvam. P, Selvakumari. S, Sivaraman D. In-vitro and In-vivo anticancer activity of Ethanolic extract of Canthium parviflorum Lam on DLA and Hela celllines. Int. J. Drug Dev. \& Res. 2011; 3(4):28085 . 